\title{
NOTES
}

\section{UNION-INDUCED EMPLOYER REFUSALS TO DEAL: A MERGER OF ANTITRUST STANDARDS AND NLRB EXPERTISE SUGGESTED}

Restraints of trade by organized labor, handled piecemeal by Congress and Court, ${ }^{1}$ occasion an anomalous juxtaposition of Taft-Hartley proscription and antitrust immunity. Because section twenty of the Clayton Act, designed to protect union activity from judicial interference, ${ }^{2}$ had been narrowly construed in antitrust suits, ${ }^{3}$ Congress passed the Norris-LaGuardia Act to forbid federal injunctions in most labor disputes. ${ }^{4}$ By infusing the legislative purpose 1948).

1. Cf. Amazon Cotton Mill Co. v. Textile Workers Union, 167 F.2d 183, 186 (4th Cir.

2. 38 Stat. 738 (1914), 29 U.S.C. $\$ 52$ (1952). The section denies federal courts authority to enjoin specified acts "involving, or growing out of, a dispute concerning terms or conditions of employment." The final clause of the section, the so-called catch-all provision, reads: "[N]or shall any of the acts specified in this paragraph be considered or held to be violations of any law of the United States." This clause was ultimately held to make acts which are not enjoinable under the section immune from antitrust sanctions as well. United States v. Hutcheson, 312 U.S. 219, 232 (1941), discussed note 5 infra. For a contrary reading of the catch-all provision, see Steffen, Labor Activities in Restraint of Trade: The Hutcheson Case, 36 ILc. L. REv. 1, 24 (1941). Acts protected by $\S 20$ are, inter alia: striking and "persuading others by peaceful means so to do"; peaceful picketing; refusing to patronize a party to a labor dispute and "persuading others by peaceful ... . means so to do."

3. See Bedford Cut Stone Co. v. Journeymen Stone Cutters' Ass'n, 274 U.S. 37 (1927) (antitrust injunction granted restraining union members from refusing to handle materials manufactured by "men working in opposition to our organization"). Earlier, the Court had construed $\$ 20$ as not extending antitrust exemption "beyond the parties affected in a proximate and substantial ... sense by the cause of dispute," and enjoined union efforts to persuade customers not to purchase nonunion-made machinery. Duplex Printing Press Co. v. Deering, 254 U.S. 443, 472 (1921). The narrow construction given $\$ 20$ by federal courts generally is set forth in FrANKFuRTER \& GREENE, The LABOR INJuncrion 165-76 (1930). The Supreme Court in the Hutcheson case, see note 5 infra, later found union activity similar to that in the Bedford and Duplex cases to be immune from the antitrust laws by virtue of the Norris-LaGuardia and Clayton Acts read together. Still later, however, $\$ 8(\mathrm{~b})(4)$ (A) of the Taft-Hartley Act made activities such as those in Bedford and Duplex, in so far as they were directed toward employees of the third-party employers, unfair labor practices subject to injunction and damage actions. See notes 11-13 infra and accompanying text. Remarks on the floor of the Senate explaining the purpose of $\S 8(\mathrm{~b})(4)$ (A) indicate agreement with the rationale of the Eedford and Duplex decisions. 93 Cong. REc. 4198-99 (1947). Senator Taft, chairman of the Senate Committee on Labor and Public Welfare and floor manager of the TaftHartley bill in the Senate, said: "All this provision of the bill does is to reverse the effect of the law as to secondary boycotts." Id. at 4198 .

4. The key provisions of the Norris-LaGuardia Act are $\S \S 4,13.47$ Stat. 70, 73 (1932), 29 U.S.C. $\S \S 104,113$ (1952). Subject to the limited exceptions of $\S 7$, 47 Stat. 
of Norris-LaGuardia into section twenty, the Supreme Court deduced congressional intent to exempt unions pursuing their own self-interest from antitrust strictures. ${ }^{5}$ Accordingly, federal courts permit restraints on trade caused by union activities or collective bargaining agreements which affect working conditions, ${ }^{6}$ so long as unions do not aid and abet unlawful con-

71 (1932), 29 U.S.C. $\$ 107$ (1952), § 4 denies federal courts authority to enjoin anyone "interested in" a labor dispute, "in any case involving or growing out of any labor dispute," from, inter alia: striking, joining a union, peaceful picketing, peacefully inducing a strike. Section 13 (c) defines the term "labor dispute" to include "any controversy concerning terms or conditions of employment . . regardless of whether or not the disputants stand in the proximate relation of employer and employee." Compare this language with that of the Duplex Court, quoted note 3 supra. The courts have given broad scope to Norris-LaGuardia. E.g., that statute was held to protect peaceful picketing by a nonlabor group to encourage the public not to patronize a store allegedly discriminating against Negroes in its hiring policies. New Negro Alliance v. Sanitary Grocery Co., 303 U.S. 552 (1938). But see Turnstall v. Brotherhood of Lacomotive Firemen, 323 U.S. 210 (1944) (federal court may enjoin union from discriminating against Negroes in bargaining unit). See, generally, 2 CCH LAB. L. REP. If 6475 (1957) (collecting cases).

5. United States v. Hutcheson, 312 U.S. 219 (1941). A carpenters' union engaged in a jurisdictional dispute with a rival union struck an employer under contract with the rival union and caused work to stop on construction projects on his and adjoining premises. Defendant union was held protected by statute against criminal prosecution for alleged Sherman Act violations. The court relied on an "interlacing" of NorrisLaGuardia's injunctive immunities, see note 4 supra, and the catch-all provision of $\$ 20$ of the Clayton Act, see note 2 supra. The Court has been criticized for invoking dubious congressional intent in Norris-LaGuardia rather than forthrightly giving a broad construction to $\$ 20$. Note, 54 HARv. L. REv. 887, 888 (1941). This criticism finds support in the indictment, which challenged union efforts to persuade customers not to patronize a struck company, conduct permitted by $\$ 20$ of the Clayton Act but not mentioned in $\S 4$ of Norris-LaGuardia. See notes 2, 4 supra.

The Hutcheson Court indicated that some union conduct such as that in United States v. Brims, 272 U.S. 549 (1926), remained unprotected. 312 U.S. at 232 n.3. In Brims, millwork manufacturers and contractors in Chicago consented to employ only union carpenters, and the union agreed not to work on the nonunion-made millwork of the Chicago manufacturers' out-of-state competitors. All parties to the combination were found to have violated the antitrust laws. The Supreme Court in effect followed the Hutcheson dictum on Brims in Allen Bradley Co. v. Local 3, Int'l Brotherhood of Elec. Workers, 325 U.S. 797 (1945), discussed note 7 infra.

6. Prior to United States v. Hutcheson, supra note 5, some lower federal courts indicated that union activities or collective agreements remotely affecting terms and conditions of employment and directly in restraint of trade might be enjoinable despite the Norris-LaGuardia Act. Scavenger Serv. Corp. v. Courtney, 85 F.2d 825 (7th Cir. 1936) ; cf. United States v. International Fur Workers Union, 100 F.2d 541 (2d - Cir. 1938) (criminal prosecution). Following Hutcheson, the Supreme Court suggested that virtually any union-inspired activity or contract is protected by Norris-LaGuardia if it affects terms and conditions of employment. United States v. American Federation of Musicians, 318 U.S. 741 (1943), affirming 47 F. Supp. 304 (N.D. III. 1942); United States v. International Hod Carriers Dist. Council, 313 U.S. 539, affirming United States v. Carrozzo, 37 F. Supp. 191 (N.D. IIl. 1941). But disputes over the hour of delivery of goods to a customer or the method of collecting bills were later held too remote to be protected by Norris-LaGuardia. Bakery Sales Drivers Union v. Wagshal, 333 U.S. 437 
spiracies among employers. ${ }^{7}$ Although litigation has not determined the

(1948), criticized in 16 U. CHI. L. REv. 169. Unprotected union objectives were also found in American Federation of Musicians v. Stein, 213 F.2d 679 (6th Cir.), cert. denied, 348 U.S. 873 (1954) (breach of commercial contract); I. P. C. Distributors, Inc. v. Chicago Moving Picture Machine Operators Union, 132 F. Supp. 294 (N.D. I1l. 1955), 56 CoLuM. L. REv. 280 (1956) (refusal to show specific motion picture).

The effect of Norris-LaGuardia immunity in actions under statutes other than the antitrust laws is unclear. Compare In re Third Ave. Transit Corp., 192 F.2d 971 (2d Cir. 1951) (Bankruptcy Act), with Baltimore \& O.R.R. v. Chicago A. \& I.R.R., 170 F.2d 654 (7th Cir. 1948), cert. devied, 336 U.S. 944 (1949) (Interstate Commerce Act).

Columbia River Packers Ass'n v. Hinton, 315 U.S. 143 (1942), apparently leaves union efforts to organize independent contractors unprotected by Norris-LaGuardia. See Gulf Coast Shrimpers Ass'n v. United States, 236 F.2d 658 (5th Cir.), cert. denied, 352 U.S. 927 (1956). But see Aetna Freight Lines, Inc. v. Clayton, 228 F.2d 384 (2d Cir. 1955), cert. denied, 351 U.S. 950 (1956). Whether unions should be able to fix prices of independent contractors is analyzed in Note, 67 YALE L.J. 98 (1957). One court has indicated that union efforts to fix prices are per se unprotected. Hawaiian Tuna Packers, Ltd. v. International Longshoremen's Union, 72 F. Supp. 562, 566-67 (D. Hawaii 1947), 61 HARv. L. REV. 549 (1948).

7. Allen Bradley Co. v. Local 3, Int'1 Brotherhood of Elec. Workers, 325 U.S. 797 (1945). Although defendant union was enjoined from participating in a conspiracy of manufacturers and contractors to monopolize the New York City market, the Court said that if the union did not aid and abet an unlawful interemployer conspiracy, it could legally establish the same monopoly on its own. Id. at 807, 809-10. The final decree conformed with this dictum. Allen Bradley Co. v. Local 3, Int'1 Brotherhood of Elec. Workers, 164 F.2d 71, 75 (2d Cir. 1947). Subsequent decisions have followed the Court's rationale. In each of these cases, the union was found immune from the antitrust laws since it had not aided an illegal conspiracy among employers. Hunt v. Crumboch, 325 U.S. 821 (1945) (refusing to organize one employer in closed-shop region) ; Meier \& Pohlmann Furniture Co. v. Gibbons, 233 F.2d 296 (Sth Cir.), cert. denied, 352 U.S. 879 (1956) (union-induced parallel behavior of employers) ; East Texas Motor Freight Lines v. International Brotherhood of Teamsters, 163 F.2d 10 (5th Cir. 1947) (same); Davis Pleating and Button Co. v. California Sportswear \& Dress Ass'n, Inc., 145 F. Supp. 864 (S.D. Cal. 1956) (same) ; United States v. Employing Plasterers Ass'n, 138 F. Supp. 546 (N.D. Ill. 1956) (enforcing union standards on quality of work) ; Red Owl Stores v. Amalgamated Meat Cutters, 109 F. Supp. 629, 634 (D. Minn. 1953) (compelling employer to keep customary store hours) ; Anderson-Friberg, Inc. v. Justin R. Clary \& Son, Inc., 98 F. Supp. 75, 82 (S.D.N.Y. 1951) (attempted exclusion of out-of-state products); New Broadcasting Co. v. Kehoe, 94 F. Supp. 113 (S.D.N.Y. 1950) (coercing sponsors to boycott radio station) ; Davis Mills Corp. v. Federation of Dyers, 18 L.R.R.M. 2433 (S.D. N.Y. 1946) (refusal to handle nonunion products). See also Dodd, The Supreme Court and Organized Labor, 1941-45, 58 HaRv. L. REv. 1018, 1051 (1945). But see United States v. Milk Drivers Union, 153 F. Supp. 803 (D. Minn. 1957). In Milk Drivers, defendant union was enjoined under the Sherman Act from refusing to deliver milk to stores selling at prices considered unfairly competitive with home-delivery prices, and from implementing a collective bargaining agreement provision preventing dairies from hiring vendors to sell milk to the vendors' own customers. The court based its decision on Allen Bradley but found no conspiracy among the dairies. There may well have been such a conspiracy to maintain the store price of milk. Id. at 806 . But there definitely was not an employer conspiracy to stop hiring vendors. Id. at 809 . This departure from the Allen Bradley dictum appears inadvertent.

In each of the following cases, a union was found not immune from antitrust sanctions because it had participated in a conspiracy of businessmen: United Brotherhood of Car- 
manifold restraints which may enjoy this immunity, ${ }^{8}$ proposals to restrict it are recurrent. ${ }^{9}$ Indirectly responding to such proposals, ${ }^{10}$ Congress enacted section 8(b) (4) (A) of the Taft-Hartley Act, which makes it an unfair labor practice for a union to induce employees to stop work "where an object thereof is . . . requiring any employer ... to cease doing business with any other person." 11 The act further requires that the National Labor Relations Board petition a federal court to enjoin a suspected $8(b)(4)$ (A) violation "pending the final adjudication of the Board" and, ${ }^{12}$ in section 303, gives anyone injured by the proscribed activity a separate court action for damages. ${ }^{13}$

penters v. United States, 330 U.S. 395 (1947) (union guilty under Allen Bradley rationale but conviction reversed on other grounds); United States v. Employing Plasterers Ass'n, 347 U.S. 186 (1954) (dictum); Local 175, Int'l Brotherhood of Elec. Workers v. United States, 219 F.2d 431 (6th Cir. 1955) (union aiding monopoly of employers' association); Las Vegas Merchant Plumbers Ass'n v. United States, 210 F.2d 732, 753-54 (9th Cir. 1954) (same); Philadelphia Record Co. v. Manufacturing Photo-Engravers Ass'n, 155 F.2d 799 (3d Cir. 1946) (same) ; United States v. Hamilton Glass Co., 155 F. Supp. 878 (N.D. Ill. 1957) (same) ; Lystad v. Local 223, Int'l Brotherhood of Teamsters, 135 F. Supp. 337 (D. Ore. 1955) (same).

8. See Cox, Labor and the Antitrust Lazes-A Preliminary Analysis, 104 U. PA. L. REv. 252, 271 (1955).

9. See, e.g., H.R. 9398, 84th Cong., 2d Sess. (1956); H.R. 2545, 83d Cong., 1st Sess. (1953) ; H.R. 8449, 82d Cong., 2d Sess. (1952) ; Report of tHe Attorney General's National Commitree To Study the Antitrust Laws 304 (1955) (hereinafter cited as AtT'y GEN. Rep.) ; Cox, supra note 8, at 284; 77 A.B.A. REP. 452, 479 (1952).

10. See note 14 infra.

11. 61 Stat. 141 (1947), 29 U.S.C. $\$ 158$ (b) (4) (A) (1952). This section was designed to inhibit some of the conduct to which the Hutcheson doctrine had given sweeping immunity. See note 5 supra. Thus, union efforts to enforce demands on one employer by concerted activity against that employer's suppliers or customers were generally made an unfair labor practice. See note 3 supra.

12. 61 Stat. 149 (1947), 29 U.S.C. $\$ 160$ (1) (1952). Private litigants may not obtain injunctive relief under this section. Bakery Sales Drivers Union v. Wagshal, 333 U.S. 437, 442 (1948). The Attorney General may proceed against unions under the TaftHartley Act only in case of emergency and on special order from the President. 61 STAT. 155 (1947), 29 U.S.C. \& 178 (1952).

13. 61 Stat. 158 (1947), 29 U.S.C. \& 187 (1952).

Although the elements of a violation are identical in both sections, an action for damages under $\S 303$ is wholly independent of board proceedings under $\S 8(b)(4)$. International Longshoremen's Union v. Juneau Spruce Corp., 342 U.S. 237 (1952). Consequently, a jury can award damages for an alleged violation which the Board has found did not occur. Compare United Brick Workers v. Deena Artware, Inc., 198 F.2d 637, 642-43 (6th Cir.), cert. denied, 344 U.S. 827 (1952), with NLRB v. Deena Artware, Inc., 198 F.2d 645 (6th Cir. 1952), cert. denied, 345 U.S. 906 (1953). This anomaly could be avoided by making a board finding of an alleged $8(\mathrm{~b})(4)(\mathrm{A})$ violation prerequisite to a damage action. The problems confronting solution to the converse of this anomaly through according the Board's finding conclusive weight in a subsequent trial are discussed note 50 infra.

Courts may not award punitive damages under $\$ 303$. UMW v. Patton, 211 F.2d 742, 749-50 (4th Cir.), cert. denied, 348 U.S. 824 (1954), reversing 114 F. Supp. 596 (W.D. Va. 1953). Nonetheless, speculative $\S 303$ damages may be allowed even though they appear punitive. See Curto v. International Longshoremen's Union, 107 F. Supp. 805 
In enacting sections $8(\mathrm{~b})(4)(\mathrm{A})$ and 303 , Congress manifested a policy of protecting one employer from the labor disputes of another and from union pressure designed to frustrate commercial relations. ${ }^{14}$ Difficulty in reconciling these broad inhibitions with the "right to strike" has generally led the Board and the courts to require an infringement of both statutory objectives before finding an unfair labor practice. ${ }^{15}$ Consequently, the usual 8(b) (4) (A)

(D. Ore. 1952), aff'd sub nom. International Longshoremen's Union v. Hawaiian Pineapple Co., 226 F.2d 875 (9th Cir. 1955), cert. denied, 351 U.S. 963 (1956). Possibly, a Sherman Act violation may also activate $\$ 303$. I. P. C. Distributors, Inc. v. Chicago Moving Picture Operators Union, 132 F. Supp. 294, 300 (N.D. Ill. 1955) (dictum). A plaintiff choosing between a $\S 303$ and an antitrust action must weigh the treble damages of the latter against the less difficult proof of the former. See notes 52, 60 infra.

14. See S. ReP. No. 105, 80th Cong., 1st Sess. 8, 22 (1947); H.R. REP. No. 510, 80th Cong., 1st Sess. 43 (1947). The House also passed a provision making union activity and collective bargaining agreements in restraint of trade subject to the antitrust laws. H.R. Rep. No. 245, 80th Cong., 1st Sess. 62-63 (1947). This provision was withdrawn by the House-Senate Conference Committee and the following explanation given: "Since the matters dealt with in this section have to a large measure been effectuated through the use of boycotts, and since the conference agreement contains effective provisions directly dealing with boycotts themselves, this provision is omitted from the conference agreement." H.R. ReP. No. 510, 80th Cong., 1st Sess. 65 (1947). The reference is undoubtedly to $\S 8$ (b) (4) (A), which does not mention "boycotts" but which was described in debate as being directed against "secondary boycotts." 93 Cong. REC. 4198 (1947). Senator Taft indicated that all types of secondary boycotts brought out in committee hearings were forbidden. Ibid. If so, a boycott is not justified under \& 8 (b) (4) (A) even if a given bargaining unit so acts to protect its own labor standards. See Kovarsky, $A$ Social and Legal Analysis of the Secondary Boycott, 35 ORE. I. REv. 71, 125-28 (1956). The Supreme Court, by forbidding union refusals to work on construction projects with employees of nonunion subcontractors, has impliedly rejected the possibility that a boycott may sometimes be justified. NLRB v. Denver Bldg. Trades Council, 341 U.S. 675 (1951); Local 74, United Brotherhood of Carpenters v. NLRB, 341 U.S. 707 (1951). This result is criticized in Comment, 60 YALE L.J. 647 (1951). See also note 63 infra. For another reading of what Congress meant by "secondary boycott," see Torbert, Section $8(b)(4)(A)$ of the Taft-Hartley Law: A Study in Statutory Interpretation, 8 Rutgers I. REv. 344, 353 (1954). See also President Eisenhower's Labor Message to Congress, N.Y. Times, Jan. 24, 1958, § 7A, p. 8, col. 3. However § $S(b)(4)(A)$ is read, it clearly rejects labor's "community of interest" justification of boycotts. For the classic statement of this justification, see Duplex Printing Press Co. v. Deering, 254 U.S. 443, 479 (1921) (dissenting opinion of Brandeis, J.). See also Shulman, Labor and the Anti-trist Lazes, 34 ILL. L. Rev. 769, 776 (1940); note 3 supra.

15. The right to strike in $\$ 13$ of Taft-Hartley is limited by $\S 8(\mathrm{~b})$ (4) (A). 61 STAT. 151 (1947), 29 U.S.C. $\$ 163$ (1952); Truck Drivers Union, 6 CCH LAR. L. REP. (33 C.C.H. Lab. Cas.) 【 71051, at 95217 (D.C. Cir. Oct. 20, 1957). Senator Taft, however, described the right to strike as substantially unimpaired by $\S 8(\mathrm{~b})(4)(\mathrm{A}) .93$ CoNG. REc. 3835 (1947). See, generally, NLRB v. International Rice Milling Co., 341 U.S. 665, 673 n.8 (1951); COX, CASES ON LABOR LAW 888 n.20 (1958) (collecting congressional statements on this problem). Thus, the difficult issue is to ascertain the scope of $\$ 8(\mathrm{~b})(4)(\mathrm{A})$. See, generally, Torbert, supra note 14. Usually, that section is read to prohibit secondary but allow primary activity. See, e.g., United Ass'n of the Plumbing Industry, 110 N.L.R.B. 206 (1954); 20 NLRB ANN. Rep. 140 (1956). The primary-secondary distinction was rigidly formulated in Douds v. Sheet Metal Workers, $101 \mathrm{~F}$. Supp. 273 (E.D. N.Y. 1951). But see the same case on rehearing, 101 F. Supp. 970 (E.D.N.Y. 1952). The 
violation involves sympathy strikes or analogous conduct, as when a union in controversy with one employer causes someone else's employees to interfere with trade between the two employers. ${ }^{16}$ The policy and language of the act go further, however, and condemn union-inspired labor disputes limited to one employer but aimed at stopping him from doing business with some specific person. ${ }^{17}$ Board and courts have therefore on occasion gone further, too, in holding that a union may not induce a concerted refusal by employees to handle prefabricated or nonunion-made products. ${ }^{18}$ Whenever the union was

distinction is admittedly not self-evident. International Brotherhood of Elec. Workers v. NLRB, 181 F.2d 34 (2d Cir. 1950), aff'd, 341 U.S. 694 (1951); United Ass'n of the Plumbing Industry, supra; Marie T. Reilly, 110 N.L.R.B. 1742 (1954); see Douds v. International Longshoremen's Ass'n, 224 F.2d 455, 459 (2d Cir. 1955), 69 HARv. L. REv. 569 (1956); Millis \& Brown, Frodi the Wagner Act to Taft-Hartley 460 (1950). And it has been called irrelevant. International Rice Milling Co. v. NLRB, 183 F.2d 21, 26 (5th Cir. 1950), rev'd an other grounds, 341 U.S. 665 (1951) ; Irving v. United Brotherhood of Carpenters, 24 CCH Lab. Cas. $\int 67890$ (N.D.N.Y. 1953); Van de Water, The Secondary Boycott Provisions of Taft-Hartley: Their Potential Influenees on MakeWork Activities, 28 So. CaLIF. L. REv. 33, 37-43 (1954). Primary-secondary terminology becomes especially confusing when a union strikes an organized employer to force him to terminate business relations with an unorganized employer with whom the union has no dispute. The latter employer is nonetheless called primary and the struck employer secondary; thus, the gloss on $\$ 8(\mathrm{~b})(4)(\mathrm{A})$ is retained. See, e.g., Los Angeles Bldg. Trades Council, 105 N.L.R.B. 868, 871 (1953). The Supreme Court has found 8(b) (4) (A) violations without endorsing the primary-secondary distinction. See, e.g., International Brotherhood of Elec. Workers v. NLRB, 341 U.S. 694, 699-700 (1951).

16. See, e.g., Amalgamated Meat Cutters v. NLRB, 237 F.2d 20 (D.C. Cir. 1956); NLRB v. Chauffeurs Union, 212 F.2d 216 (7th Cir. 1954) ; NLRB v. United Brotherhood of Carpenters, 184 F.2d 60 (10th Cir. 1950). On the problem of picketing an employer sharing a common situs with another employer, see NLRB v. International Brotherhood of Teamsters, 234 F.2d 296 (5th Cir. 1956); Sheet Metal Workers, 115 N.L.R.B. 1137 (1956) ; Note, 45 GEo. L.J. 614 (1957). Where employers are "allies," they may be treated as one. NLRB v. Business Mach. Mechanics Conference Bd., 228 F.2d 553 (2d Cir. 1955) ; United Brotherhood of Carpenters, 40 L.R.R.M. 1171 (NLRB 1957), rev'd sub nom. J. G. Ray and Sons Co. v. NLRE, LAB. REI. REP. (41 L.R.R.M. 2445) (1st Cir. Jan. 27, 1958); see Note, 10 VAND. L. REv. 457, 459 (1957) (collecting cases). On "roving-situs" picketing, see NLRB v. Associated Musicians, 226 F.2d 900 (2d Cir. 1955) (union prohibited from picketing employees at second employer's premises); Note, 42 VA. L. REv. 363 (1956).

17. See note 14 supra. Section 8(b) (4) (A) in terms applies to any union-induced concerted activity "where an object thereof is ... forcing or requiring any employer ... to cease doing business with any other person." 61 STAT. 141 (1947), 29 U.S.C. $\S$ 158(b) (4) (A) (1952). See Torbert, supra note 14, at 353; cf. NLRB v. Denver Bldg. Trades Council, 341 U.S. 675 (1951), 100 U. PA. L. Rev. 141, 143, 37 VA. L. Rev. 1012, 1014.

18. NLRB v. Local 11, United Brotherhood of Carpenters, 242 F.2d 932 (6th Cir. 1957), board decision, 113 N.L.R.B. 1084 (1955); NLRB v. Local 1976, United Brotherhood of Carpenters, 241 F.2d 147 (9th Cir.), cert. granted, 355 U.S. 808 (1957), board decision, 113 N.L.R.B. 1210 (1955); NLRB v. Washington-Oregon Shingle Weavers' Dist. Council, 211 F.2d 149 (9th Cir. 1954), board decision, 101 N.L.R.B. 1159 (1952) ; Joliet Contractors Ass'n v. NLRB, 202 F.2d 606 (7th Cir.), cert. denied, 346 U.S. 824 (1953), board decision sub nom. Glaziers' Union, 99 N.L.R.B. 1391 (1952); 
not engaged in a controversy with the manufacturer of the boycotted products, these cases reflected congressional policy not against the spread of labor disputes but against unions acting in restraint of trade. ${ }^{19}$ To some as yet imprecise extent, then, a union is prohibited from intentionally encouraging concerted activity to gain an employer's agreement to terminate business relations with a third party. ${ }^{20}$

Although Taft-Hartley could thus render a union enjoinable or liable in damages for inducing a strike in restraint of trade, a collective bargaining agreement imposing similar restrictions on business alternatives would enjoy broad legal immunity. ${ }^{21}$ Concerted activity to make an employer stop buying

Roumell v. United Ass'n of the Plumbing Industry, 151 F. Supp. 706 (E.D. Mich. 1957) ; Irving v. United Brotherhood of Carpenters, $24 \mathrm{CCH}$ Lab. Cas. If 67890 (N.D.N.Y. 1953); Bott v. Glaziers' Union, 15 CCH Lab. Cas. గ 64859 (N.D. I11. 1948) ; Local 1016, United Brotherhood of Carpenters, 117 N.L.R.B. 1739 (1957). See also Chauffeurs Union, 101 N.L.R.B. 1284 (1952).

The Board has yet to agree unanimously that a dispute limited to one employer can fall within the proscription of $\$ 8(\mathrm{~b})(4)(\mathrm{A})$. E.g., two of the five members subscribed to the following views in Local 1976, United Brotherhood of Carpenters, 113 N.L.R.B. 1210,1225 (1955) (dissenting opinion): 'Where, as in the instant case, a union's objective is clearly and unmistakably limited to a primary dispute, involving an employer's contractual obligation, the fact that this dispute may in some manner affect other employers with whom the union has no dispute at all does not mean that 'an object' of the union is to reach these employers and engage in secondary conduct within the meaning of Section S(b) (4) (A)." This minority position was unanimously rejected by the Ninth Circuit in NLRB v. Local 1976, United Brotherhood of Carpenters, supra.

19. In no case cited in note 18 supra did the union have a present dispute with the manufacturer of the boycotted product.

20. Several of the cases cited in note 18 stpra can be explained in part as prohibitions against refusals to handle nonunion goods because of a potential labor dispute between the boycotted employer and the boycotting union. See Irving v. United Brotherhood of Carpenters, $24 \mathrm{CCH}$ Lab. Cas. I 67890 (N.D.N.Y. 1953). But this explanation is not fully satisfactory. The cases do not distinguish between unions boycotting employers who have been identified as the makers of the boycotted product and unions boycotting any nonunion product regardless of origin. In fact, the Board has indicated that such a distinction would be irrelevant. Local 1976, United Brotherhood of Carpenters, 113 N.L.R.B. 1210, 1214 (1955). But cf. Washington-Oregon Shingle Weavers' Dist. Council, 101 N.I.R.B. 1159, 1165 (1952) (dissenting opinion). Furthermore, the cases do not distinguish between unions objecting to a product because nonunion-made and unions objecting because it is also prefabricated and therefore takes work from the protesting employees. See Local 11, United Brotherhood of Carpenters, 113 N.L.R.B. 1084, 1095 (1955). An element in all of these cases is that requiring unions to handle the disputed products enables the manufacturer to market them. Whenever a union is enjoined from boycotting the products of an employer on whom the union has not made demands, the court is protecting that employer's commercial outlets; it is denying employees resort to concerted activity aimed at permanently closing those outlets. "Although a desire to 'make work' and its implementation do not necessarily violate Section 8 (b) (4), when the implementation involves requiring one employer to cease doing business with another, its illegality becomes plain." Glaziers' Union, 99 N.L.R.B. 1391, 1395 n.13 (1952). Com pare id. at 1398 (dissenting opinion).

21. A collective bargaining agreement is immune from the antitrust laws so long as it is not part of an interemployer conspiracy itself unlawful. See note 7 supra. For a 
a certain product, for example, would be enjoined, but a contract binding him not to buy that product would be allowed. ${ }^{22}$ The distinction does not reflect antistrike policy since a specific purpose, not the strike itself, is the basis of the unfair labor practice; a union that manifests the prohibited purpose is enjoined whether or not the strike occurs. ${ }^{23}$ Nor is the distinction suggested by antitrust policy; the strike is prohibited and damages allowed however reasonable its restraint on commercial competition and great its potential service to working conditions, while the contract, however grave its effect on competition and insubstantial its benefit to labor, is permitted. ${ }^{24}$ Similarly, the distinction cannot be explained as a preference for consensual agreements since the union may obtain the contract by threatening to strike or picketing customers. ${ }^{25}$ It is simply an anomaly which has given rise to further anomalies, notably the "hot cargo" clause in which an employer agrees to countenance concerted activity. ${ }^{26}$

summary of the criteria used by courts in determining the existence of an illegal interemployer conspiracy, see Levy, Multi-Earployer Bargaining and the Antitrust Laws 81-82 (1949).

22. Compare Roumell v. United Ass'n of the Plumbing Industry, 151 F. Supp. 706 (E.D. Mich. 1957) (union enjoined from inducing employees to refuse to handle rival union-made pipe), with Davis Pleating and Button Co. v. California Sportswear \& Dress Ass'n, 145 F. Supp. 864 (S.D. Cal. 1956) (contracts forbidding employers to purchase nonunion-made products are not antitrust violations).

23. NLRB v. Associated Musicians, 226 F.2d 900, 904-05 (2d Cir. 1955); Local 745, Dallas Gen. Drivers, 40 L.R.R.M. 1349 (NLRB 1957); Local 50, Bakery Workers Union, 115 N.L.R.B. 1333, 1341 (1956). The NLRB probably may infer intent to induce a strike from "the natural and probable consequences" of union activity within a given fact situation and without specific findings of actual intent. See Radio Officers' Union v. NLRB, 347 U.S. 17, 44-46 (1954). But such a bare inference by the Board is likely to receive an unenthusiastic judicial reception. NLRB v. Business Mach. Mechanics Conference Bd., 228 F.2d 553 (2d Cir. 1955); cf. Intermountain Equipment Co. v. NLRB, 239 F.2d 480 (9th Cir. 1956). On whether use of unfair employer lists constitutes inducement, see Amalgamated Meat Cutters, 93 N.L.R.B. 336 (1951). See also International Ass'n of Machinists, LAB. REL. REp. (41 L.R.R.M. 1058) (NLRB Nov. 4, 1957); Note, 62 Y ALE L.J. 1111 (1953).

24. Compare the reasoning of the court in Joliet Contractors Ass'n v. NLRB, 202 F.2d 606 (7th Cir. 1953) (single refusal of three glaziers to handle preglazed sash constitutes an 8(b) (4) (A) violation), with that in Anderson-Friberg, Inc. v. Justin R. Clary \& Son, Inc., 98 F. Supp. 75 (S.D.N.Y. 1951) (collective bargaining agreement closing New York market to Vermont-finished granite would be legal).

25. Schatte v. International Alliance of Theatrical Employees, 182 F.2d 158, 165 (9th Cir. 1950) (threatening strike) ; Local 878, Int'l Brotherhood of Teamsters, 92 N.L.R.B. 255 (1950) (same) ; NLRB v. Business Mach. Mechanics Conference Bd., 228 F.2d 553, 559 (2d Cir. 1955) (picketing customers); Local 47, Int'l Brotherhood of Teamsters, 112 N.L.R.B. 923, 925 (1955) (same); see Note, 38 VA. L. Rev. 481, 489 (1952) ; cf. Bay State Hats, Inc. v. Rose, $30 \mathrm{CCH}$ Lab. Cas. 70054 (S.D.N.Y. 1956). See also Tower, Secondary Boycotts and the Taft-Hartley Act: Some Suggestions for Amendment, 21 Geo. Wash. L. Rev. 547, 571-72 (1953). Compare Madden v. General Teamsters Union, 141 F. Supp. 459, 462 (E.D. Wis. 1956) (inducing "fear" constitutes $8(\mathrm{~b})(4)(A)$ violation).

26. In such clauses, an employer agrees that employees may refuse to work on products of which the union disapproves. See Comment, 25 U. CHI. L. REv. 182 (1957); 
These anomalies are symptoms of the need for comprehensive congressional policy on union-inspired contracts that constrict businessmen's activity in the market place. At present, the public and injured third-party businessmen have no legal remedy against either party to such a contract. ${ }^{27}$ Now that labor unions are often strong enough to prevent employers from doing business with

Note, 64 Y ALE L.J. 1201 (1955). For example, the union may obtain an agreement not to purchase goods produced by an employer currently being picketed, Milk Drivers Union v. NLRB, 245 F.2d 817 (2d Cir. 1957), or by an employer whose employees are not union members, NLRB v. Local 1976, United Brotherhood of Carpenters, 241 F.2d 147 (9th Cir.), cert. granted, 355 U.S. 808 (1957). The clause itself is legal under antitrust doctrine as developed since Allen Bradley. Meier \& Pohlmann Furniture Co. v. Gibbons, $113 \mathrm{~F}$. Supp. $409-10$ (E.D. Mo. 1953), aff'd, 233 F.2d 296 (8th Cir.), cert. denied, 352 U.S. 879 (1956); see note 7 supra. Difficulty arises, however, when a union attempts to invoke the clause not by seeking employer co-operation but by inducing employees to concerted activity in a manner forbidden by $\$ 8(\mathrm{~b})$ (4) (A). See, e.g., Madden v. General Teamsters Union, supra note 25. The five-member NLRB has split four ways on the status of these clauses. Two members consider a clause prima facie evidence of an 8 (b) (4) (A) violation if the employer is a common carrier. Otherwise, they presumably agree with a third member who feels that a union's calling the clause to employees' attention constitutes inducement prohibited by $\S 8(\mathrm{~b})(4)$ (A). A fourth member says that the clause is "invalid at its inception." The fifth member finds such clauses and union enforcement thereof legal. Truck Drivers Union, LAB. REI. REP. (41 L.R.R.M. 1087) (NLRB Nov. 8, 1957). The circuits have also divided. General Drivers Union v. NLRB, 247 F.2d 71 (D.C. Cir.), cert. granted, 355 U.S. 808 (1957) (clause enforceable by union self-help); Milk Drivers Union v. NLRB, supra (same); NLRB v. Local 1976, United Brotherhood of Carpenters, supra (enforcing clause by union self-help violates $\& 8(\mathrm{~b})(4)(\mathrm{A})$ ). For a suggested approach to hot-cargo clauses, see note 60 infra.

27. See, generally, notes 4-7 supra. Of course, if the contract were part of an employer conspiracy, it would be subject to antitrust regulation. United States v. Women's Sportswear Manufacturers Ass'n, 336 U.S. 460, 464 (1949).

The available remedy for injury as a result of a hot-cargo clause is presently in dispute. See note 26 supra. If the employer honors the clause by not using union-condemned products, no "concerted activity" and hence no $8($ b) (4) (A) violation has occurred. Nor has an antitrust violation. Sherman, Boycotts, Strikes and Damages, 5 LAB. L.J. 617, 631 (1954). If the employer does not honor the clause until the union tells him to, there is still no violation. Cf. Rabouin v. NLRB, 195 F.2d 906, 911-12 (2d Cir. 1952). But if the union induces employees to refuse to handle goods covered by the agreement, even with the employer's consent, $\S \$($ b) (4) (A) may be violated. General Drivers Union, 115 N.L.R.B. 800 (1956), rev'd, 247 F.2d 71 (D.C. Cir.), cert. granted, 355 U.S. 808 (1957), 42 MINN. L. REv. 502 (1958).

The remedy of specific performance is available in a federal district court for breach of a collective bargaining agreement under $\$ 301$ of Taft-Hartley. Textile Workers Union v. Lincoln Mills, 353 U.S. 448 (1957). That case dealt with a failure to arbitrate in conformance with a collective agreement. Specific performance may be granted, said the Court, because "the failure to arbitrate was not a part and parcel of the abuses against which the [Norris-LaGuardia] Act was aimed." Id. at 458. A collective agreement in restraint of trade may not be enjoined because of Norris-LaGuardia immunity. See notes 47 supra. Whether or not breach of such an agreement may be enjoined under Lincoln Mills has not been litigated. Cf. Mendelsohn, Enforceability of Arbitration Agreements Under Taft-Hartley Section 301, 66 YaLE L.J. 167, 179-83 (1956). For criticism of the Court's decision in Lincoln Mills, see Bickel \& Wellington, Legislative Purpose and the Judicial Process: The Lincoln Mills Case, 71 HaRv. L. Rev. 1 (1957). 
selected third parties, ${ }^{28}$ the commercial consequences should be approached as such and not only when a strike happens to be in progress. ${ }^{29}$ Otherwise, the law will continue to reward unions which can obtain employer agreements merely by threatening labor trouble and to penalize rival unions unable to achieve such agreements short of strike. ${ }^{30}$ Conceivably, the Supreme Court could take notice of the present power and practices of unions, reverse earlier decisions and attempt to solve these problems. ${ }^{31}$ But this endeavor would necessitate a case by case determination of proper union objectives without the aid of specific legislative guidance; $; 2$ and, absent a comprehensive national

28. The hot-cargo clause problem indicates that strong or strategically placed unions are frequently able to choose among third-party businessmen in contract negotiations. See 2 CCH LAB. L. REp. đ 5220.34-366 (1957) (collecting cases). See also Cox, supra note 8 , at $266-67$.

29. Strikes or concerted activity necessarily frustrate business relations. If such relations are protected, it is not from strikes, themselves protected under $\$ 7$ of TaftHartley, 61 STAT. 140 (1947), 29 U.S.C. $\$ 157$ (1952), but from union objectives inconsistent with commercial competition, see Apex Hosiery Co. v. Leader, 310 U.S. 469, 493-97, 500-11 (1940); note 56 infra; cf. Steffen, Labor Activities in Restraint of Trade: The Apex Case, $50 \mathrm{Y}_{\mathrm{ALE}}$ L.J. 787, 823-26 (1941). For an analysis showing strikes to have been legal under the common law, see Boudin, The Sherman Act and Labor Disputes: II, 40 Colum. L. Rev. 14, 50 (1940). For a criticism of the rigid antitrust doctrine applied to unions under the Sherman Act, see Shulman, supra note 14, at 777-78.

30. See notes 25, 28 supra; cf. Rabouin v. NLRB, 195 F.2d 906, 911-12 (2d Cir. 1952).

31. Thus, the Court could modify the sweeping scope given the Norris-LaGuardia Act by the Hutcheson and Allen Bradley doctrines. See notes 5-7 supra. The theory of those decisions was that Congress intended to allow unions to resort to self-help to the full extent of their self-interest. This theory is supported by those who fear judicial determination of "good" and "bad" objectives of labor activity. Nathanson \& Wirtz, The Hutcheson Case: Another View, 36 ILI. L. REv. 41, $54-55$ (1941). It has been criticized as avoiding judicial responsibility to injured parties, see Steffen, Labor Activities in Rcstraint of Trade: The Hutcheson Case, 36 ILL. L. REv. 1, 36 (1941), and as economically unrealistic, Mason, Econonic Concentration and the Monopoly Problem 210-12 (1957) (hereinafter cited as MAsoN). For an earlier Court view, see Apex Hosiery Co. v. Leader, 310 U.S. 469, 495-97 (1940) (only concerted activity to suppress competition is illegal).

32. In view of Congress's repeated refusal to make "labor disputes" subject to the antitrust laws, the Court presumably could not attempt to reach union activity under the antitrust laws except by qualifying the term "labor dispute." For a list of bills seeking to restrict antitrust immunity which have been proposed but rejected in Congress, see note 9 supra; cf. Allen Bradley Co. v. Local 3, Int'1 Brotherhood of Elec. Workers, 325 U.S. 797, 807 \& n.12 (1945) ; Hawaiian Tuna Packers, Itd. v. International Longshoremen's Union, 72 F. Supp. 562, 566 (D. Hawaii 1947), 61 HARv. L. Rev. 549 (1948). See also note 14 supra.

Judicial reformulation of the term "labor dispute" on an ad hoc basis could easily turn into a means of emasculating $\S 20$ of the Clayton Act and Norris-LaGuardia. See Cox, supra note 8, at 269. New Yorks "little Norris-LaGuardia Act" has been so treated; as a result, judges may stop strikes with which they are not in agreement. See Cox, The Role of Lare in Labor Disputes, 39 CoRNeLr L.Q. 592, 597 (1954) (analyzing and collecting cases). In the absence of legislation defining permissible labor disputes, judges might be well advised to resist the temptation to make such a determination on their own. 
policy, the Board could require an employer to bargain in good faith on a contract provision, which, if agreed to, might be construed by a district court as violating the antitrust laws. ${ }^{33}$ Any classification of union-induced employer promises into the licit and illicit should, therefore, come from Congress. ${ }^{34}$

Unions seek employer promises in order to minimize wage competition or promote job security. ${ }^{35}$ Different approaches are used to achieve these goals.

Duplex Printing Press Co. v. Deering, 254 U.S. 443, 488 (1921) (dissenting opinion of Brandeis, J.). Congress passed the Norris-LaGuardia Act in response to just such judicial interference. Cox, CASES on LABOR LAw 100 (1958). For an analysis advocating the Brandeis approach, see Bickel \& Wellington, supra note 27, at 29.

33. The NLRB and federal district courts owe no obedience to one another. Cf. Fitzgerald v. Douds, 167 F.2d 714 (2d Cir. 1948); note 13 supra. The Board may require good-faith collective bargaining on a specific issue. Cf. Allis-Chalmers Mfg. Co. v. NLRB, 213 F.2d 374 (7th Cir. 1954); note 46 infra. If such bargaining resulted in a contract in restraint of trade, absent controlling national policy a district court would be free to declare the contract illegal. For example, the Board has required an employer to bargain on union demands that he limit the amount of work subcontracted. Timken Roller Bearing Co., 70 N.L.R.B. 500, 518 (1946). But cf. Administrative Decision of NLRB General Counsel, No. 996, CCH LAB. L. REP. 1954-55 Transfer Binder \ 52185 (1954) (apparently inconsistent with Timken). But a federal district court has found an agreement limiting the hiring of contractors unlawfully to restrict the entry of competitors in a given market. United States v. Milk Drivers Union, 153 F. Supp. 803, 808-09 (D. Minn. 1957). But see note 7 supra.

34. Cf. United States v. Hutcheson, 312 U.S. 219, 232 (1941).

35. Unionism necessarily implies "an agreement among workers not to compete for jobs." Mason 196; see Bakfe, Mutual Survival, the Goal of Unrons and ManAGEMENT 7-S (1946). The propriety of union monopoly in labor markets is frequently acknowledged by economists, and such markets are often thought economically distinguishable from product markets. Brown, Labor and Antitrust Laws 23 (M.I.T. Pub. in Social Science, Ser. 2, No. 64, 1955). Critical analysis, however, indicates the inextricability of labor and product markets. See MAsos 215-18. For a pre-Hutcheson case in which the court attempted to weigh encouragement of product competition against discouragement of wage competition, see Gundersheimer's, Inc. v. Bakery Workers' Union, 119 F.2d 205 (D.C. Cir. 1941). But cf. Sheet Metal Workers Union, 102 N.L.R.B. 1660 (1953) (product competition not considered in ruling on jurisdictional dispute under $\S$ $8(\mathrm{~b})(4)(A))$. Some economists feel that labor-market monopoly is incompatible with commercial competition. E.g., Simons, Some Reflections on Syndicalism, in LABOR Relations and the Law 49, 51-52 (Mathews ed. 1953); Lindblon, Unions and Capitalisas 5 (1949). Others argue for restriction of industry or market-wide unionization but recognize the desirability of some degree of labor-market monopoly. E.g., Chamberlain, The Monopoly Pozer of Labor, in THE IMPPact of THE UNION 175-88 (Wright ed. 1951). Mason 207 concludes that labor-market monopolies have no predictable effect on commercial competition and that their size is a political, not an economic, question. Cf. Cox, supra note 8, at 277-79.

Under $\S 6$ of the Clayton Act, courts are bound not to enjoin the formation of labor organizations. 38 Stat. 731 (1914), 15 U.S.C. \& 17 (1952). Prior to the NorrisLaGuardia Act, however, courts invariably found antitrust violations if union activity overtly interfered with commerce. BERMAN, LABOR AND tHe SHERMan ACT c. 10 (1930). With one exception, the rule of reason was not applied during this period. Id. at 233 . The exception was National Ass'n of Window Glass Manufacturers v. United States, 263 U.S. 403 (1923) (opinion of the Court per Holmes, J.), analyzed in LEvY, MULTI- 
One is to enter into contracts preventing commercial relations with shops whose competition a union desires to avoid. ${ }^{36}$ Yet these contracts cause the sort of injury to boycotted businesses which Congress sought to prevent by curtailing concerted activity in section 8 (b) (4) (A)..$^{37}$ Substantially the same goals can be attained without such injury, however, through a collective agreement securing the bargaining unit's wage levels for the duration of the contract. $^{38}$ Furthermore, a union can eliminate the wage competition of rival

EArployer Bargaining and the Antitrust Laws 13-15 (1949). Subsequent to the Norris-LaGuardia Act, the antitrust division of the Justice Department attempted to distinguish permissible union monopoly practices from illegal ones, but with little success. Mason 199-200. But cf. Steffen, Labor Activities in Restraint of Trade: The Apex Case, 50 Yale L.J. 787, 821 (1941) ; Miller, Antitrust Labor Problems: Law and Policy, 7 Law \& Contensp. ProB. 82, 88-89 (1940). In Apex Hosiery Co. v. Leader, 310 U.S. 469 (1940), the Supreme Court said that union activity is permissible if price competition is not affected, but the implications of this distincton were left undeveloped when the Court next term decided the Hutcheson case. See note 5 supra.

36. See, e.g., East Texas Motor Freight Lines v. International Brotherhood of Teamsters, 163 F.2d 10 (5th Cir. 1947) ; Davis Pleating and Button Co. v. California Sportswear \& Dress Ass'n, Inc., 145 F. Supp. 864 (S.D. Cal. 1956), 43 VA. L. REv. 99 (1957) ; Lystad v. Local 223, Int'1 Brotherhood of Teamsters, 135 F. Supp. 337 (D. Ore. 1955).

37. See notes 14, 18, 19 supra; of. Van de Water, supra note 15, at 37-43. See also note 39 infra.

38. Unterberger, Guaranteed Wage \& Supplensentary Unearployment Pay Plans 9-13, 21-22 (1956) ; see Hansen, Economic Policy and Full Employment 15860 (1947). An employer must bargain in good faith on union proposals seeking job and wage stability. See W. W. Cross \& Co. v. NLRB, 174 F.2d 875 (1st Cir. 1949) ; Inland Steel Co. v. NLRB, 170 F.2d 247 (7th Cir. 1948). For a case in which the union demanded that the employer either preserve present wages or cease purchasing labor-saving equipment, see United States v. Carrozzo, 37 F. Supp. 191 (N.D. Ill.), aff'd sub nom. United States v. International Hod Carriers Dist. Council, 313 U.S. 539 (1941). In such a case, the union can achieve its objective by allowing the purchase but demanding the preservation of wage levels. Cf. Cox, supra note 8 , at 274.

Current job security plans are described in Solomon, The Guaranteed Annual Wage and Other Types of Job Security Plans-An Explanation and Analysis, 7 WesterN Res. L. REv. 117 (1956). Such plans have been criticized as too costly in unstable and unnecessary in stable industries. Backman, Economics of the Guaranteed Wage, 7 LAB. L.J. 623, 628 (1956). And public unemployment benefits have been called preferable to a guaranteed annual wage. Weisenfeld, An Alternative to the Guaranteed Amnal Wage, 6 LAв. L.J. $679,685-87$ (1955). Neither objection was directed to the relative desirability of unionimposed boycotts or job-security contracts. To the extent that a union with sufficient bargaining power to obtain an employer refusal to deal could also obtain a wage-stability clause, the choice would be between the social utility of boycotts and wage maintenance. Boycotts designed to eliminate third-party businessmen from trade are admittedly against public policy. ATT'y GEN. REP. 137. Guaranteed wage plans, on the other hand, have been recommended as nationally desirable in themselves, OfFICE OF WAR Mobilization \& Reconversion, Guaranteed Wages, Report to the President by the Advisory BoArd 453-56 (1947), and as stabilizers against depression, Hansen, Monetary Theory and Fiscal Policy 124-29 (1949); Keynes, General Theory of Entployment, IntereST ANd MONEy 260-69 (1935). See also Ruttenberg, Pay by the Year, Harper's, Dec. 1955, p. 29. But see Leeman, The Guaranteed Anmual Wage, Employment and Economic 
shops by organizing them. ${ }^{39}$ Therefore, congressionally favored union objectives would still be served if antitrust immunity for a union choosing among third-party businessmen were limited to collective agreements conditioning trade relations on compensatory benefits for adversely affected employees of

Progress, \& IND. \& LAB. ReL. Rev. 565 (1955) (job security-contracts bring about reduced wage rates and/or rate of investment). Other problems implicit in wage guarantees are computation under the Fair Labor Standards Act, Mitchell v. Hartford Steam Boiler Inspection and Ins. Co., 235 F.2d 942 (2d Cir. 1956), 6 Duke B.J. 128 (1957), and eligibility for state unemployment compensation, Note, 69 HARv. L. REv. 362 (1955).

39. Unions are generally protected from management interference in their organizational efforts. 6 NLRB ANN. REP. 41-43 (1941). Leading cases are Republic Aviation Corp. v. NLRB, 324 U.S. 793 (1945) ; International Ass'n of Machinists v. NLRB, 311 U.S. 72 (1940). But hostile employers as well as unions are guaranteed the right to noncoercive speech during a union election campaign, and the union as a practical matter may be at a disadvantage. See Livingston Shirt Corp., 107 N.L.R.B. 400 (1953). Moreover, the right to distribute literature on an employer's premises may be restricted when the solicitors are union professionals. NLRB v. Babcock \& Wilcox Co., 351 U.S. 105 (1956). But an employer may be prevented from excluding a union from public meeting places in a company town. NLRB v. Stowe Spinning Co., 336 U.S. 226 (1949), 27 N.C.L. REv. 562 . On the problem of organizing competing independent contractors, see Milk Drivers' Union v. Lake Valley Farm Products, Inc., 311 U.S. 91 (1940) (unionization allowed), 26 Cornell L.Q. 328 (1941); Note, 67 Yale L.J. 98 (1957).

Organizational picketing is an unfair labor practice if it follows on the heels of defeat in a representation election; such activity is said to "coerce" employees in violation of $\S$ 8(b) (1) (A), 61 STAT. 141 (1947), 29 U.S.C. $\S 158$ (b) (1) (A) (1952). International Ass'n of Machinists, LAB. ReE. ReP. (41 L.R.R.M. 1058) (NLRB Nov. 4, 1957) ; Drivers Union, LAB. Rel. Rep. (41 L.R.R.M. 1025) (NLRB Oct. 30, 1957), 42 MinN. L. Rev. 459 (1958). Were organizational picketing further restricted, it might be argued that unions must therefore be allowed to obtain contracts boycotting competing shops. More logically, however, if Taft-Hartley prohibits unionization by picketing, the act must forbid all boycotts having the same purpose. And boycotts for organizational purposes, if brought about by union-induced concerted activity, can violate $\S 8(\mathrm{~b})(4)(B)$ as well as § S(b) (4) (A). 61 STAT. 141 (1947), 29 U.S.C. $\$ 158(\mathrm{~b})(4)(\mathrm{B})$ (1952); International Union of Operating Engineers, 115 N.L.R.B. 23, 29 (1956); cf. United Brick Workers v. Deena Artware, Inc., 198 F.2d 637 (6th Cir.), cert. denied, 344 U.S. 897 (1952) (inducing organizational boycott violates $\S 8(b)(4)(A)$ but not $\S 8(B)(4)(B)$ ).

Since unions are generally protected in their organizational campaigns, public policy dictates that such campaigns rather than contractual boycotts be encouraged. Unionization brings the advantages of collective bargaining to the employees of rival shops, and, in industry-wide bargaining situations, eliminates competitive wage-cutting. Hoxie, Collective Bargaining and the Trade Union Program, in Unrons, MANAGEMENT AND THE Public 358-61 (Bakke \& Kerr ed. 1948). Boycotts, on the other hand, isolate rival shops from markets and, when not accompanied by organizational campaigns, do not even offer those shops a means of regaining their markets. Cf. Cox, supra note 8, at 282-83. And a contractual boycott terminable on the success of an organizational campaign may now constitute unlawful coercion of the employees of the rival shop. See International Ass'n of Machinists, supra; cf. Note, 42 MinN. L. Rev. 459, 469 (1958). In any event, $\S 8(\mathrm{~b})(4)$ (A) was designed to protect employees from being coerced into unions by economic boycotts effected through concerted activity. See 93 CoNG. REc. $4834-37$ (1947). If the boycott is the result of a collective agreement, the effect on the employees of the rival shop is the same. 
the contracting employer. ${ }^{40}$ The result would be to forbid refusals to deal, otherwise in violation of antitrust law, when caused either by explicit union proscription or by union-imposed conditions not designed to preserve the em-

40. This solution to the problem of collective agreements not to deal is subject to the following criticism.

Employees who object to working on nonunion or rival-union-made goods are injured in a noncompensable manner when required to handle such goods; their only recourse is to secure an employer promise not to deal. To the extent that employees find nonunionmade goods personally repugnant, this objection is valid. Cf. NLRB v. Denver Bldg. Trades Council, 341 U.S. 675, 692 (1951) (dissenting opinion; refusal to work on same job with nonunion men); MIrlirs \& Brown, From the Wagner Act to TAfT-Hartley 468-70 (1950). But the suggested approach would not make an agreement an antitrust violation if the contested product were actually injurious to employees' health. United States v. Bay Area Painters Joint Comm., 49 F. Supp. 733 (N.D. Cal. 1943). And if a contract were bona fide reflecting only employees' dislike of handling nonunion goods, the elements of an antitrust violation would probably be lacking. See note 51 infra. However, the boycott is more likely to be for the purpose of enforcing union objectives proscribed by $\S 8$ (b) (4) (A) and possibly $\S 8(\mathrm{~b})(1)(A)$ in the case of concerted activity. See note 39 supra. (For the argument that 8 (b) (4) (A) policy is wrong in not permitting union boycotts for certain purposes, see note 63 infra.)

The proposed solution does not solve the conflict between an employer's desire to reduce labor costs and a union's pursuit of job security. This conflict is essentially not justiciable. Slichter, Consequences of Job-Security Efforts of Unions, in Unrows, Management and the Public 568, 573-74 (Bakke \& Kerr ed. 1948). Legislation could establish a tribunal authorized to pass on the validity of wage agreements; Congress has, however, refused to adopt this approach. See 93 Cong. Rec. 6441, 6443, 6859 (1947). Consequently, the anti-featherbedding provision in Taft-Hartley is virtually a dead letter. See NLRB v. Gamble Enterprises, Inc., 345 U.S. 117 (1953) ; American Newspaper Publishers' Ass'n v. NLRB, 345 U.S. 100 (1953). The conflict has thus been left to the bargaining table. The knottiest policy problem arises when an employer seeks purchases allowing more efficient production methods but resulting in layoffs of employees. Arguments for technological advance and against the rigors of unemployment in such situations are antithetically compelling and of comparable national concern. See Hearings Before the Subcommittee on Economic Stabilization of the Joint Committee on the Economic Report, 84th Cong., 1st Sess. 106-11, 265-66, 425-56 (1953) ; cf. Cox, Some Aspects of the Labor Management Relations Act, 1947, 61 HARv. L. Rev. 274, 288-89 (1948); Diebold, Automation-The New Technology, Harv. Bus. Rev., Nov.-Dec. 1953, pp. 63, 69-70.

Suppose an employer buys product $X$ for $\$ 1$, adds processes $A, B$ and $C$, each at a labor cost of $\$ 1$, and thereby produces $Z$. If he can buy $X$ with process $A$ already added (product $Y$ ) at any price less than $\$ 2$, it will be more efficient to lay his $A$ employees off. Cf. United States v. Painters' Dist. Council, 44 F.2d 58 (N.D. Ill. 1930), aff'd, 248 U.S. 582 (1931). Under the proposed solution, antitrust policy, i.e., national policy promoting efficiency through competition, ATT'Y GEN. REP. 1-3, would be applicable if a union contracted to prevent the purchase of $Y$. The union would thus be confined to bargaining for employment of $A$ employees in the $B$ and $C$ departments, for unemployment or job termination benefits and for pensions. The latter two benefits could not exceed present $A$ wages; otherwise, the union would have sought and gained more than preservation of present labor standards. Whether the employer purchased $Y$ would depend upon the relation of the benefits won by the union to the difference between cost of purchasing $Y$ and producing $X$ plus $A$, and on his ability to utilize or place the $A$ employees elsewhere. In an extreme case, if the union won the equivalent of total current wages for all $A$ employees for the rest of their lives, if the employer could not use $A$ 
ployees' present labor standards. ${ }^{41}$ Within this framework, a union could maintain job security and the fruits of a labor-market monopoly by requiring employers to make up for unfavorable changes in working conditions. But efforts to attain that monopoly or security through the exclusion of businessmen from the marketplace would be subject to antitrust scrutiny. ${ }^{42}$

Antitrust liability would depend on the purpose as well as the effect of an alleged union-induced refusal to deal. ${ }^{43}$ Once outright interdictions lost antitrust immunity, union-caused boycotts would in all likelihood result from con-

employees and buy $Y$, and if $Y$ were but one cent cheaper than $X$ plus $A$, then the employer would not buy $Y$ unless he could foresee ultimate savings in excess of union-won benefits in the form of avoidance of rising labor costs, attrition of $A$ employees through death, retirement or placement with other employers, reduction in the cost of $Y$, etc.

41. See note 51 infra. If an employer were purchasing labor-saving equipment which enabled employees to do the same work in less time, a collective agreement conditioning such purchases on increased compensation could reflect no more than consequent loss in take-home pay, or increased worker efforts through a resulting speed-up. The achievement of higher wages for handling nonunion or rival-union-made products than for handling other products of the same sort would be unprotected for antitrust purposes. No restriction should be imposed, however, on wage or benefit raises not designed to inhibit specific external business relationships.

42. This inhibition would embrace unions seeking agreements to effect the organization of other shops, e.g., Amalgamated Meat Cutters v. NLRB, 237 F.2d 20 (D.C. Cir. 1956), cert. denied, 352 U.S. 1015 (1957), the exclusion of competing products or services, c.g., NLRB v. Washington-Oregon Shingle Weavers' Dist. Council, 211 F.2d 149 (9th Cir. 1954), or the pursuit of both goals, e.g., Milk Drivers Union v. NLRB, 245 F.2d $\$ 17$ (2d Cir. 1957). The use of economic coercion to organize other shops violates the policy behind $\$ \$ S(b)(1)(A), \&(b)(4)(A),(B)$. See note 39 supra. Thus, such coercion should be prohibited when it involves contractual refusals to deal constituting an unreasonable restraint on trade. See note 51 infra. The exclusion of rival goods or services raises the issues of efficiency and security discussed note 40 supra; note 64 infra. The hardest of these cases concern limitations on the employer's capacity to contract out work. E.g., Rabouin v. NLRB, 195 F.2d 906 (2d Cir. 1952). If the employer's motive is not purely economic but in part reflects his attitude toward a union or unionism, he is guilty of an unfair labor practice. Somerset Classics, Inc., 90 N.L.R.B. 1676 (1950), aff'd, 193 F.2d 613 (2d Cir. 1952); Gerity Whitaker Co., 33 N.I.R.B. 393 (1941); see Allis-Chalmers Mfg. Co. v. NLRB, 162 F.2d 435, 440 (7th Cir. 1947). See also Comment, 34 B.U.L. REv. 237, 239-40 (1954). The penalty for such an unfair labor practice is reinstatement of, and payment of lost wages to, the employees discriminated against. Piedmont Cotton Mills, 79 N.L.R.B. 1218 (1948). This penalty, as was early noted, is an effective one. Ward, Proof of "Discrimination" Under the National Labor Relations Act, 7 GEo. WASH. L. REv. 797, 800 (1939). If the employer's motive in contracting out work is purely economic, the union's proper remedy is organizing the bargaining unit to which work has been contracted, see note 39 supra, and/or obtaining compensatory benefits for work actually lost by the original employees, see note 40 supra. To allow the union entirely to forbid contracting out work would sanction insulation of relative inefficiency, a frequently short-term achievement resulting in the employer closing down his business altogether, see Mount Hope Finishing Co. v. NLRB, 211 F.2d 365 (4th Cir. 1954); Brown-McLaren Mfg. Co., 34 N.L.R.B. 984 (1941), as well as ignore antitrust principles.

43. See Associated Press v. United States, 326 U.S. 1, 14-15 (1945); ATT'y GEN. REP. 132-37. 
ditions imposed on specified dealings. ${ }^{4}$ The status of a given refusal to deal would then turn on whether the conditions were intended to compensate employees for the adverse effects of the business relationship or to forbid that relationship altogether. ${ }^{45}$ This issue, principally involving a finding of purpose in union demands, naturally falls within the expertise and the collective bargaining jurisdiction of the NLRB. ${ }^{46}$ Although board resolution of this critical question of fact would delay court adjudication of the ultimate antitrust issues, it would assure accuracy and uniformity. ${ }^{47}$ These latter considerations appear more compelling, especially since the Board prior to its decision could in appropriate cases petition a district court for injunctive relief needed

44. Rather than invite antitrust scrutiny by entering into a contract forbidding use of, e.g., rival-union products, a union would probably prefer to attach a wage premium to such use. $C f$. the union objective in Sheet Metal Workers Ass'n, 102 N.L.R.B. 1660 (1953). Rather than prohibit by collective agreement the sale of a product to certain distributors, a union might seek contract terms the ultimate effect of which would be to prevent such distribution. See United States v. Milk Drivers Union, 153 F. Supp. 803, 808-09 (D. Minn. 1957).

45. See note 41 supra.

46. The Board has authority to infer unlawful purpose from foreseeable effects and a given situation as a whole. Radio Officers' Union v. NLRB, 347 U.S. 17, 44-46 (1954); Republic Aviation Corp. v. NLRB, 324 U.S. 793, 800 (1945). And the Board's expertness in making such an inference is recognized by reviewing courts. Universal Camera Corp. v. NLRB, 340 U.S. 474,488 (1951); NLRB v. Minnesota Mining \& Mfg. Co., 179 F.2d 323, 325-26 (8th Cir. 1950); see Cox, The Right To Engage in Concerted Activities, 26 IND. L.J. 319, 344 (1951).

Although the scope of collective bargaining is not specifically entrusted to board supervision, through precedent and practice the NLRB has become arbiter of what issues are bargainable as well as what constitutes good-faith bargaining. 13 NLRB ANN. REP. 62 (1948); Cox \& Dunlop, Regulation of Collective Bargaining by the National Labor Relations Board, 63 HARv. L. Rev. 389, $397-98$ (1950) ; cf. 20 NLRB ANN. REp. 96-97 (1956).

47. See Gelimorn \& Byse, Administrative Law 4-5 (1954); cf. Barnes, Unions and the Antitrust Laws, 7 LAB. L.J. 133, 178 (1956). In cases in which an unequivocal contractual prohibition existed, district courts could readily handle the initial issue of purpose. However, less forthright provisions could not be so easily interpreted; accordingly, all cases should be first routed through the NLRB.

The NLRB's decision would be declaratory in nature; no order would issue. If the contract were found designed to prevent a particular commercial relationship rather than to preserve present labor standards, an interested party would be permitted to initiate antitrust proceedings. See note 49 infra. The proposed declaratory decision-making could follow existing NLRB procedural rules for handling unfair labor practices under $\S 3$ (d), 10 of Taft-Hartley. 61 STAT. 139, 146 (1947), 29 U.S.C. $\$ \$ 153$ (d), 160 (1952). Thus, if a formal charge were filed alleging injury from a contract designed to prevent business dealings, General Counsel of the Board, if satisfied of the legal sufficiency of the charge, would issue a complaint against the parties to that contract and seek a board decision declaring it to be for the alleged purpose.

The Board should be statutorily directed to render a declaratory decision if the collective agreement at issue is one "affecting commerce." Otherwise, the Board's selfimposed jurisdictional limitations might prevent prosecution of an antitrust violation. See 39 L.R.R.M. 44-59 (1957) for those limitations. Of course, a congressional mandate un- 
to prevent irreparable injury. ${ }^{48}$ If the Board determined a union aim other than compensation for probable labor losses, antitrust proceedings could follow. ${ }^{49}$ The district court would ascertain the purpose and scope of the boycott and evaluate its restrictions on the accessibility of commercial markets. ${ }^{50}$ If under antitrust criteria a person or class were unreasonably excluded

accompanied by sufficient appropriations to handle all such cases would solve nothing. See Mulis \& Brown, op. cit. supra note 40, at 34 n.7.

To avoid easy evasion, the procedures suggested in this Note should not be restricted to cases involving formal collective bargaining agreements. Any employer agreement or understanding should be subject to the same procedures.

48. If the Board had reasonable cause to believe that the contract provision at issue was aimed at particular business dealings and went beyond protection of present labor standards, it could apply to a district court for an injunction. The court would have to be satisfied both of reasonable cause to believe that an antitrust violation had occurred and of irreparable injury preventable only by injunction. A similar procedure is currently followed under $\S 10(1)$. Cf. note 12 stupra and accompanying text. For the standards applied by federal district courts on application for an injunction under $\S$ 10(1), see Douds v. International Longshoremen's Ass'n, 242 F.2d 808, 810 (2d Cir. 1957); Schauffler v. Highway Truck Drivers, 230 F.2d 7, 9 (3d Cir. 1956). See also Douds v. Milk Drivers Union, 40 L.R.R.M. 2669 (2d Cir.), motion for stay denied, 40 L.R.R.M. 2673 (2d Cir. 1957).

49. If respondent parties in the NLRB proceeding received an adverse board decision, appeal would lie to a court of appeals having jurisdiction under $\S 10$ of Taft-Hartley. See note 47 supra. Antitrust proceedings would be delayed in the event such an appeal were taken. The sole issue on appeal would be whether the board decision was supported by substantial evidence. See note 42 supra. Allowing such an appeal would probably be preferable to awaiting review after a lengthy trial on antitrust issues in a district court.

The government or an allegedly injured private party should be able to toll the statute of limitations for antitrust purposes by becoming a charging party to the NLRB proceedings. See note 48 supra; cf. AtT'y Gen. ReP. 380-85; Note, 53 Coluar. L. Rev. 1115 (1953). To avoid possible inconsistent application, an interested party for purposes of both the NLRB proceeding and the antitrust suit should be defined. See $\$ 4$ of the Clayton Act, 38 Star. 731 (1914), 15 U.S.C. $\$ 15$ (1952) (defining interested party). In any event, the government would be an interested party if it chose to initiate NLRB or court proceedings.

50. If the board finding were treated as conclusive proof that the contract was designed to do more than preserve present labor standards, uniform application of NLRB criteria for assessing union purpose would be assured and inconsistent determinations by finders of fact avoided. Cf. United Brick Workers v. Deena Artware, Inc., 198 F.2d 637, 642-43 (6th Cir. 1952). Making the board finding conclusive rather than evidentiary would, however, deprive unions of the right enjoyed by other defendants to take all issues to the jury. In a criminal case, moreover, this deprivation might violate constitutional guarantees. U.S. CoNsT. art. III, § 2; id. amend. VI; United States ex rel. Toth v. Quarles, 350 U.S. 11, 18 (1955).

Whatever its proper evidentiary weight in proving a contract purpose unprotected by the labor laws, a board finding would not establish unlawful purpose under the antitrust laws. Even if conclusive, an NLRB finding of intent to frustrate some commercial relationship would not be tantamount to a finding of coercive or monopolistic design required to establish an antitrust violation. Unlawful antitrust purpose would, therefore, remain an issue for the district court. See Times-Picayune Publishing $C_{0}$. v. United States, 345 U.S. 594, 625-28 (1953), 67 Harv. L. Rev. 128, 131. 
from a significant market, ${ }^{51}$ civil or criminal sanctions could be imposed. ${ }^{52}$

51. The following types of antitrust cases could arise:

Single Employer. Unless a union contract with a single employer were an element in a scheme otherwise unlawful under the antitrust laws, a consequent refusal to deal should be legal. For an employer may select those with whom he deals so long as his selection is not part of a price-control conspiracy or manifestation of monopoly power. United States v. Colgate \& Co., 250 U.S. 300, 307 (1919) ; United States v. Bausch \& Lomb Co., 321 U.S. 707, 722-24 (1944); AtT'y GeN. Rep. 135; Barber, Refusals To Deal Under the Federal Antitrust Lazes, 103 U. PA. L. Rev. 847, 861-62 (1955); Comment, 58 YALE L.J. 1121, 1134-35 (1949). To the extent that an employer is free to decide with whom he will deal, he should be free to agree with his employees to this end. But where this agreement becomes the instrument of monopoly power, the parties thereto should be considered in violation of $\S 2$ of the Sherman Act, 26 STAT. 209 (1890), 15 U.S.C. $\$ 2$ (1952). Cf. Eastman Kodak Co. v. Southern Photo Materials Co., 273 U.S. 359 (1927). And a collective agreement conditioning sales or purchases on illegal price arrangements would itself be illegal under $\$ 1,26$ STat. 209 (1890), 15 U.S.C. $\$ 1$ (1952). See Barber, supra at 851-57. For a recent case on what constitutes a lawful refusal to deal, see Packard Motor Car Co. v. Webster Motor Car Co., 243 F.2d 418 (D.C. Cir. 1951) (cancellation of franchise). See also note 58 infra and accompanying text, discussing retention of the existing unfair labor practice proscription of union-induced agreements designed to make a third-party employer capitulate in a labor dispute.

Group Boycott. Where a union has entered into one or several contracts with more than one employer binding all to the same boycott provision, the antitrust law of group boycotts should govern. Here, the union has done more than influence a single employer's discretion to pick his customers and suppliers. See ATT'y GEN. REP. 137. If the boycott is designed to coerce nonconforming businessmen, it would be a per se antitrust violation. Eastern States Lumber Dealers' Ass'n v. United States, 234 U.S. 600 (1914) ; Barber, supra at 872-76; Kirkpatrick, Connnercial Boycotts as Per Se Violations of the Shernan Act, 10 GEO. WASH. L. REv. 387, 402-05 (1942). But if the union contract were regulative of the conduct of its employer adherents among themselves, its legality might depend on the reasonableness of any attendant restraints on trade. Associated Press v. United States, 326 U.S. 1 (1945) ; United States v. Insurance Bd., 144 F. Supp. 684 (N.D. Ohio 1956) ; Barber, supra at 876-79; Comment, 51 Nw. U.L. Rev. 628 (1956).

Since a "union" would be liable for the effects of various contracts or agreements, precise definition of "union" is essential. Any union local or association of locals should be responsible for antitrust consequences of their agreements. Cf. $\$ 2(5)$ of Taft-Hartley, 61 Stat. 138 (1947), 29 U.S.C. \$ 152(5) (1952) (defining "labor organization"). For jurisdictional difficulties in suing a union, see Comment, 66 Y ALE L.J. 712, 738-41 (1957).

Since union participation in interemployer conspiracies is presently unlawiul, see note 7 supra; Levy, Multi-Enployer Bargaining and the Antitrost Laws 81-82 (1949), the antitrust procedure and criteria suggested in this Note are pertinent only in the absence of illegal employer conspiracies.

52. In a private suit under $\S 4$ of the Clayton Act, the recovery is treble damages plus all litigation costs. 38 STAT. 731 (1914), 15 U.S.C. $\$ 15$ (1952). Revision of $\$ 4$ to allow lesser damages in appropriate cases has been recommended. ATr'y GEN. REP. 378-80. See Segal \& Mullinix, Administration and Enforcement, 104 U. PA. L. REv. $285,306-08$ (1955). A private plaintiff may also obtain equitable relief. Id. at 286 . In a civil suit brought by the government, the court issues appropriate decrees "to extirpate practices that have caused or may hereafter cause monopolization, and to restore workable competition in the market," usually in the form of injunction (divorcement, dissoIution or divestiture orders would probably be inapplicable in the present context). United States v. United Shoe Mach. Corp., 110 F. Supp. 295, 347 (1953), aff'd, 347 U.S. 521 (1954). A successful criminal prosecution can entail fines and/or imprisonment under 
But the employer who can show that his conduct was necessary to avert or end a strike should not be subjected to liability. ${ }^{\text {s3 }}$

Strikes or work stoppages to force employer refusals to deal-if not in furtherance of external disputes 54 -could be handled in the same manner as similarly motivated provisions in collective agreements. ${ }^{55}$ Specifically, unilateral union activity could be judged in terms of the employer concession sought. ${ }^{\text {to }}$ The NLRB should again make the initial finding of purpose since it is better equipped for this function than the courts. ${ }^{57}$ When, however, the

$\S \S 1,2$ of the Sherman Act. As a matter of administrative policy, criminal prosecutions are reserved for flagrant offenses. ArT'Y GEN. REP. 350-51; see Berge, Remedies Available to the Government Under the Sherman Act, 7 LAw \& CONTEMr. ProB. 104 (1940).

53. The employer, as a necessary party to the alleged offending agreement, would be a defendant to any suit arising out of the agreement. He should be permitted to become a charging party, however, in case he was struck for demands which, if granted, would result in such an agreement. See note 55 infra.

54. If a union struck employer $A$, a supplier or customer of employer $B$, in furtherance of an active dispute with $B$, the strike could be enjoined under $\$ 8(b)(4)(A)$. See note 60 infra.

55. A union attempt to coerce an agreement in restraint of trade could be handled similarly to a case in which the union had obtained the agreement. Care should be taken, however, that judicial processes do not interfere with the give and take of collective bargaining but are brought into play only if and when a union has embarked on a course of economic coercion to obtain an illegal agreement. Cf. Schatte v. International Alliance of Theatrical Employees, 182 F.2d 158, 165 (9th Cir. 1950).

56. Because of the generally preferred status of concerted union activity, see NLRB v. International Rice Milling Co., 341 U.S. 665, 673 (1951), the type of strike or work stoppage or refusal to handle goods which is to be subjected to antitrust proceedings should be defined with utmost specificity. Activity looking to changes in wages, hours or working conditions should generally remain immune. Only refusals to work intentionally aimed at obtaining an employer agreement to sever a given commercial relationship should be restricted. And union activity in response to an outside labor dispute should be treated exclusively under Taft-Hartley. See note 58 infra. Whether a strike seeking to impose conditions on commercial relations should be the subject of antitrust proceedings presents difficult problems. Certainly, realistic standards are necessary for finding a definite intent to sever certain relations. The fact that a union is striking for high benefits should be viewed in light of the conventional bargaining technique of demanding larger concessions than will ultimately be accepted. See Chamiberlain, Collective Bargaining Procedure 20-21 (1944). Presumably, the NLRB is equipped to apply such standards. See note 46 supra.

For other areas in which concerted activity has been denied its usually protected status, see NLRB v. Reynolds \& Manley Lumber Co., 212 F.2d 155 (5th Cir. 1954) (endangering property); American News Co., 55 N.L.R.B. 1302 (1944) (strike for illegal wage raise); Administrative Decision of NLRB General Counsel, No. K-2, CCH LAB. L. Rep. 1955-56 Transfer Binder f 52995 (1955) (refusal to make up time lost on job). See also NLRB v. Local 1229, Int'l Brotherhood of Elec. Workers, 346 U.S. 464 (1953) (disloyalty to employer); International Union, United Automobile Workers v. Wisconsin Employment Relations Bd., 336 U.S. 245, 26465 (1949) (intermittent, unannounced work stoppages); Note, 67 YALE L.J. 325 (1957).

57. See note 46 supra. See also notes 47-49 supra.

Indeed, the case is often put much more strongly, viz., that courts are institutionally unfitted for handling labor disputes. See Bickel \& Wellington, supra note 27, at 22-25; 
Board finds that a union was coercing an employer to agree to boycott a third party with whom the union had no controversy, jurisdiction over the challenged activity as an unfair labor practice should not be retained. Rather, court proceedings should follow to determine the antitrust implications of the agreement which union success would have effected. Only when the Board concludes that concerted activity was designed to make a third-party employer capitulate in a union dispute should section $8(\mathrm{~b})(4)(\mathrm{A})$ be applied. ${ }^{\text {s8 }}$ One

Shulman, Reason, Contract and Law in Labor Relations, 68 HARv. L. Rev. 999, 1024 (1955) ; Cox, The Role of Lawe in Labor Disputes, 39 CoRnell L.Q. 592, 602-03 (1954) ; cf. Millis \& Montgomery, Organtzed Labor 639-40 (1945). Congress has, however, permitted courts to determine the purpose of concerted activity in damage actions under $\S 303$ of Taft-Hartley. See note 13 supra. This section was added on the floor of the Senate, and the omission of the NLRB from its provisions was explained by Senator Taft as follows: "We considered making it a procedure through the National Labor Relations Board also, but it is not felt, I think, by any of those on the other side of these questions that the Labor Board is an effective tribunal for the purpose of trying to assess damages in such a case." 93 CoNG. REC. 4858 (1947). Those on the other side of the question concentrated their fire on the word "unlawful" in $\$ 303$. Accordingly, the artless prohibition, "unlawful, for the purposes of this section only," was substituted on the floor, and $\S 303$ then passed. 93 CoNG. REC. 4858-64, 4874-75 (1947). Evidently, Congress did not debate the problem of judicial fact-finding in an area of theretofore exclusive NLRB primary jurisdiction, nor notice that $\$ 303$ permits two distinct fact-finders to pass on the same alleged violation. See note 13 supra. Nor did the debate cited above articulate the basic difficulty in categorizing the $\$ 303$ offense, namely, that $\S 303$ was aimed not at a crime but at an unfair labor practice described in $\S 8(\mathrm{~b})(4)(\mathrm{A})$ and necessarily under board jurisdiction.

If the Board had reasonable cause to believe that concerted activity was aimed at winning an employer agreement not to deal, it could apply for an interlocutory injunction when necessary to prevent irreparable harm. But the injunction is an unsatisfactory means of handling concerted activity, hence the Norris-LaGuardia Act. See Note, 48 Colum. L. REv. 759, 765-66 (1948). An injunction should be sought by the Board only when a union clearly is using force, or about to use force, to compel an employer to agree to give up some commercial relationship. Presumably, the Board so acts under $\$ 10(1)$ in seeking injunctions of suspected 8 (b) (4) (A) violations. See note 12 stpra and accompanying text; cf. Tables, 20 NLRB ANN. REP. 177-83 (1955). Only where the NLRB is reasonably certain of illicit intent, and the court of a potential antitrust violation and irreparable harm, should an injunction issue. See note 58 infra.

58. Since, absent external disputes, frustration of commercial relations is the keystone of 8 (b) (4) (A) proscriptions, see text at note 14 supra, concerted activity designed neither to preserve present labor standards nor to achieve capitulation by a third-party employer should, like its embodiment in contract, be judged by relevant antitrust criteria. Retention of unfair labor practice jurisdiction by the Board would either unduly delay ultimate antitrust proceedings or, because of the sweeping language of $\S 8(\mathrm{~b})(4)(A)$, proscribe activity not violative of antitrust law and thus continue, albeit in a new form, the anomalous distinction between unilateral union efforts and their bilateral outgrowth. E.g., in Irving v. United Brotherhood of Carpenters, $24 \mathrm{CCH}$ Lab. Cas. If 67890 (N.D. N.Y. 1953), the union caused four workers to refuse to install nonunion-processed lumber on a given project. The court enjoined this refusal under $\$ \&(\mathrm{~b})$ (4) (A) although the union had no active dispute with the lumber manufacturer. Since the refusal was in accordance with union rules, this manufacturer may well have been the object of concerted boycotts by many union locals. But no evidence on this point was deemed necessary : 
goal of that section-protection against other employers' labor disputescould thus be subserved.59 And judicial implementation of the other-curtailing union obstruction of commercial relations-through resolution of business disruption cases unconnected with external labor disputes would insure that antitrust as well as labor policy achieved expression. ${ }^{60}$

the boycott was per se enjoinable. Proper application of antitrust criteria would require evidence that a union had done more than force a single employer to agree to do what he legally could do anyway. See note 51 supra. And union refusal to handle certain goods should not be prohibited unless an employer agreement to the same end would be illegal. Otherwise, unions would be held to higher antitrust standards than employers. The antitrust laws should not be read to inhibit physical interruption of commerce by union selfhelp, see Apex Hosiery Co. v. Leader, 310 U.S. 469, 500-01 (1940), but to deny unions the right to obtain contracts regulating commerce in a manner forbidden to employers, $c f$. Cox, supra note 8, at 266-67. Therefore, the fact that an employer has been or will be struck for illegal aims should not be controlling; whether fulfillment of these aims would result in an unreasonable restraint on trade is the essential question. Cf. the issue in American News Co., 55 N.L.R.B. 1302 (1944).

59. See text at note 14 supra. The built-in conflict between $\S \S 8(\mathrm{~b})$ (4) (A) and 303 would remain, however. See note 13 supra.

60. This approach would enable Board and courts rationally to restrain activity violating 8 (b) (4) (A) policy whether or not a union was spreading a labor dispute from one economic unit to another. The subterfuge of finding a "background" dispute between union and boycotted employer when there is no actual dispute could be abandoned. Often problematical, this background dispute is found to label the union's activity "secondary." See, e.g., Marie T. Reilly, 110 N.L.R.B. 1742 (1954). See also Irving v. United Brotherhood of Carpenters, 24 CCH Lab. Cas. If 67890, at 84644-45 (N.D.N.Y. 1953). In one case, the Supreme Court observed that a background dispute existed but did not rely on this observation in finding an $8(\mathrm{~b})(4)$ (A) violation. NLRB v. Denver Bldg. Trades Council, 341 U.S. 675,688 (1951). On the fallacious foundation of the background-dispute doctrine, see Van de Water, supra note 15, at 37-43. The necessity for this doctrine arose from congressional condemnation of all boycotts without distinction between those furthering external disputes and those against "someone the union does not like." See remarks of Senator Taft, 93 Cong. REC 4198 (1947). The proposed procedure would let the NLRB determine whether a boycott was in aid of an actual external labor dispute or simply a prohibition against certain business relations. If the former, an unfair labor practice would be made out and 8(b) (4) (A) sanctions against sympathy strikes appropriate. If the latter, the more demanding criteria of the antitrust laws could be applied to what is essentially an antitrust question.

This approach would also provide a basis for handling hot-cargo clauses. See note 26 supra. Absent a union purpose to make a third-party employer capitulate, a strike to obtain such a clause would be valid unless projected antitrust injury were provable. In a given fact situation, such proof might be possible; but the usual hot-cargo clause lets the union designate goods or employers to be boycotted, and, prior to that designation, the effect of the clause probably would be conjectural. See Milk Drivers Union, 116 N.L.R.B. 1408, 1417 (1956) ; cf. Comment, 25 U. CHI. L. Rev. 182, 186 (1957). Once a clause was agreed on and invoked by the union, the proper remedy could depend on two factors: whether the employer disputed union invocation of the clause and whether the union was furthering an external dispute. If the employer agreed to the invocation and ceased dealing in certain products, the Board should not exercise $8(\mathrm{~b})(4)$ (A) jurisdiction irrespective of the existence of an external labor dispute. Otherwise, $\S 8$ (b) (4) (A) would forbid employer refusals to deal not caused by the physical spreading of labor disputes solely because the employer chose to conform with employee demands. See note 
Allowing unions to condition business relations on preservation of labor standards, yet imposing antitrust restrictions on union efforts to terminate those relations, would rationalize current law and focus collective bargaining on the problems of worker efficiency and security. Instead of the present rule protecting union activity transformed into contract, ${ }^{61}$ antitrust doctrine would be applied to all union-induced refusals to deal found by the NLRB to serve purposes other than compensation for the effect of business dealings on wage or job levels. ${ }^{62}$ That doctrine should provide more discriminating and pertinent evaluation of union goals than the sweeping prohibitions of section $8(\mathrm{~b})(4)$ (A). ${ }^{63}$ Moreover, permitting unions to obtain compensatory benefits

51 supra; cf. Local 47, International Brotherhood of Teamsters, 112 N.L.R.B. 923, 925 (1955). But cf. Alpert v. United Brotherhood of Carpenters, 143 F. Supp. 371, 374-75 (D. Mass. 1956), 70 HARv. L. REv. 735 (1957) (hot-cargo clause allowing disruption of commerce injures public rights which Taft-Hartley protects and employer cannot bargain away). Antitrust proceedings, however, might be appropriate. When the employer is a common carrier, he probably could not refuse to deal but could only countenance the failure of union-represented employees to handle certain goods. Congress should clarify the status of common carriers and their employees in this area. For attempts to resolve conflicting policies, see Truck Drivers Union, LAB. ReL. Rep. (41 L.R.R.M. 1087) (NLRB Nov. 8, 1957) ; Comment, 25 U. CHI. L. Rev. 182, 186-87 (1957); cf. Quaker City Motor Parts Co. v. Inter-State Motor Freight System, 148 F. Supp. 226, 228-29 (E.D. Pa. 1957).

If the employer did not agree with union invocation of the clause, the appropriate remedy would depend on whether the union was using concerted activity to spread an external dispute to that employer. A union could be judged by antitrust criteria when attempting by concerted activity to enforce a clause solely to cut a third-party businessman off from his markets. For such a fact situation, see Local 1976, United Brotherhood of Carpenters, 113 N.L.R.B. 1210 (1955). But if a union in dispute with a third party entered into a dispute with an inmediate employer over invoking a hot-cargo clause against that third party, the second dispute could be made an 8 (b) (4) (A) violation as in effect constituting a sympathy strike. See remarks of Sentor Taft, 93 CoNG. REc. 4198 (1947). On whether such a second dispute should be allowed as an attempted enforcement of contract, compare Local 1976, United Brotherhood of Carpenters, supra at 1215, with id. at 1223-24 (dissenting opinion). This case and issue are currently pending disposition by the Supreme Court. Local 1976, United Brotherhood of Carpenters v. NLRB, 355 U.S. 808 (1957). If this means of enforcing a contract is held to be an exception to $8(\mathrm{~b})(4)$ (A) policy against spreading labor disputes, the Board would have no reason, once finding a purpose other than preservation of present labor standards, to retain jurisdiction. Antitrust proceedings could then follow.

61. See notes 22,24 supra.

62. See notes $47,48,51$ supra.

63. See notes 50,58 supra. The elements of an $8(\mathrm{~b})(4)$ (A) violation are union inducement of employees to concerted activity for the purpose of making one employer cease doing business with another. Unreasonable commercial consequences are ignored. Cf. Joliet Contractors Ass'n v. NLRE, 202 F.2d 606 (7th Cir.), cert denied, 346 U.S. 824 (1953) (discussion of arbitrary elements of an 8(b) (4) (A) violation).

Commentators have suggested that not all union boycotts are undesirable; that the law should distinguish among them on the basis of comparative wage levels of the boycotted and boycotting shops, or immediacy of the threat to labor standards, or availability of alternate union weapons. These same commentators note, however, that in adopting $\$$ 8 (b) (4) (A) Congress eschewed all such distinctions. See, e.g., MIllis \& Brown, Frox 
should encourage management and labor to take a responsible approach toward problems of productivity and job dislocation. Management would be able to choose the most efficient means of production but would be under union pressure to avoid hardship or the lowering of wage levels. And unions would be required to concentrate on gaining maximum benefits resulting from, rather than preventing, increased productivity. ${ }^{64}$

THE Wagner Act to TAFT-HARTLEy 466-67 (1950); Cox, The Role of Lawe in Labor Disputes, 39 CoRNell L.Q. 592, 605 (1954); Koretz, Federal Regulation of Secondary Strikes and Boycotts-A New Chapter, 37 CoRnel L.Q. 235, 239 (1952). In New York, the courts permit a boycott if they feel that it is properly designed to protect labor standards. The leading case is Goldfinger v. Feintuch, 276 N.Y. 281, 286, 11 N.E.2d 910, 913 (1937); see Cushman, Secondary Boycotts and the Taft-Hartley Law, 6 SYrAcuse L. Rev. 109, 110 (1954). Congress might be well advised to make a similar sort of distinction rather than, or in addition to, the one proposed here.

64. See Bakke, Organizational Problems in Collective Bargaining, in WAGE DetrRMINATION AND THE ECONONITCS OF LIBERALISAs 83, 87 (1947); note 40 supra.

Granting unions the right to secure wage and employment status in the face of new methods of production could delay the introduction of these methods; but it would constitute less of an obstacle than outright union prohibtions against business dealings needed to increase efficiency. Union pressures-which the law is probably powerless to inhibit altogether-would be given a relatively less harmful, though still effective, outlet. $C f$. Cox, The Role of Law in Labor Disputes, 39 ConNenL L.Q. 592, 602-04 (1954). More generally, in growing industries, employees who would be dislocated could frequently be employed in other jobs, and innovations in production methods brought about simultaneously. Case studies in expanding areas of the economy indicate that unions and management can establish mutually satisfactory arrangements for increasing efficiency and relocating workers. See Hearings, supra note 40, at 279-87. As indicated by gross national product, the economy as a whole has been growing in recent years at an annual rate of $4 \%$. JorNT Committree on the Economic Report, Trends in Econonic Growth $68-69$ (1955); see Economic Report of the President 1-6 (1956); Jonnt Conmittee on the Econonic Report, Potential Growth of the United States During the Next Decade 19 (1954). For an analysis of wage-security measures in an expanding economy, see HaNSEN, Economic Policy and Fuld EMroloyment 154-55 (1947). 